Original Research Paper

\title{
Mapping, Characterization and Dispersion of Metallic Pollutants within a Catchment of Illegal Gold Mining Activities in Ghana
}

\author{
${ }^{1}$ Wiafe Samuel, ${ }^{2}$ Richard Buamah, ${ }^{2}$ Helen Essandoh and ${ }^{4}$ Lawrence Darkwah \\ ${ }^{I}$ Regional Water and Environmental Sanitation Centre, Kumasi-Ghana \\ ${ }^{2}$ Department of Civil Engineering, KNUST, Kumasi-Ghana \\ ${ }^{3}$ Department of Chemical Engineering, KNUST, Kumasi-Ghana
}

Article history

Received: 07-12-2017

Revised: 02-01-2018

Accepted: 13-01-2018

Corresponding Author: Wiafe Samuel

Regional Water and

Environmental Sanitation

Centre, Kumasi-Ghana

Tel: +233208241438

Email: samwafy@yahoo.co.uk

\begin{abstract}
The illegal gold mining activities prevalent in most part of Ghana have caused substantial havoc to the environment especially water bodies which serve as sources of water for domestic, industrial and agricultural purposes. The Ghana Water Company Limited (GWCL) recently shut down their water treatment plant due to the extreme pollution and high cost of treatment. This study focusses on the impact of mining activities on water quality of the affected water bodies, to assess the level of pollution of the river sediments and the extent of dispersion of the heavy metallic pollutants and to map out areas within the Konongo Municipality where illegal mining activities are prevalent. In this regard, both water and sediment samples from two rivers namely; Owerri and Asuokofi in Konongo (in the Asante Akim Central Municipality) were collected at different locations and analysed using Flame Atomic Absorption Spectrometry (FAAS) to assess the concentrations and dispersions of metallic pollutants. Geographical Positioning System (GPS) coordinates of these sample locations were also taken for mapping the sampling points and area. Four different metals; mercury $(\mathrm{Hg})$, Lead $(\mathrm{Pb})$, Arsenic (As) and Cadmium (Cd) were analysed. For sediments, the mean levels of $\mathrm{Pb}, \mathrm{Hg}$, As and $\mathrm{Cd}$ for the owerri river were found to be $52.2 \pm 2$, $0.3 \pm 0.5,492 \pm 365$ and $1.7 \pm 2.0 \mathrm{mg} \mathrm{kg}^{-1}$ respectively; whilst those for Asuokofi river were $12 \pm 0.7,2.7 \pm 0.4,21.2 \pm 13.5$ and $1.6 \pm 0.4 \mathrm{mg} \mathrm{kg}^{-1}$ respectively. The mean levels of $\mathrm{Pb}, \mathrm{Hg}$, As and $\mathrm{Cd}$ for water of the owerri river are respectively $2.5 \pm 3.7,0.20 \pm 0.4,0.28 \pm 0.2$ and $3.1 \pm 0.4 \mathrm{mg} \mathrm{L}^{-1}$; whilst those for Asuokofi river were $8.2 \pm 1.3,2.3 \pm 1.8,25.4 \pm 22.2$ and $0.45 \pm 0.7 \mathrm{mg} \mathrm{L}^{-1}$ respectively. Comparing these levels with the WHO standards for water discharges, these concentrations far exceeded the recommended values. This will impact negatively on the quality of both rivers with dire consequences since they serve as the main raw water resource for drinking water production. Samples of sediments and water from the upstream of these rivers where no activity of alluvial mining is taken place were recorded and they showed lower levels of these metals. It can therefore be concluded that the activities of alluvial gold mining in the study area impacts negatively on both the quality of water in the river and the sediments thereof.
\end{abstract}

Keywords: Heavy Metals, Illegal Mining, Pollutant and Water Quality

\section{Introduction}

The illegal gold mining activities prevalent in most part of Ghana have caused irreparable havoc to the environment especially water bodies which serve as sources of water for domestic, industrial and agricultural purposes. Pollution of surface water bodies with mercury, cadmium, Arsenic and lead etc. have been the order of the day due to illegal mining. For instance, it is reported that the Birim and Densu Rivers in the Eastern region which serve as a source of raw water for several communities have gravely been affected by small-scale 
gold mining activities. The ten regions in Ghana have most of their urban and peri-urban communities supplied with drinking water that is produced from surface water bodies'. The Pra and Ankobra Rivers in the Western region as well as other smaller rivers and streams have also not been spared (Amankwah, 2013). A research conducted by Oduro et al. (2012) found out that the main Pra river and its tributaries have $48 \pm 26$ and $27 \pm 18 \mathrm{ppb}$ average dissolved $\mathrm{Hg}$ concentration respectively which are far above the WHO guideline value of $1.0 \mathrm{ppb}$. This has been attributed to illegal gold mining activities along that stretch. In two of the regions (Eastern and Brong Ahafo regions) the GWCL recently shut down their water treatment plant due to the extreme pollution and high cost of treatment being incurred by the company.

In Ghana, it is established that human activities is the basic source of environmental $\mathrm{Hg}$ and other metallic pollution (Hilson and Pardie, 2006) and this is due to the inappropriate method of amalgamating the gold particles (Swain et al., 2007). Metallic pollutants generally do not remain at the place of discharge but travel along the flow lines of the receiving rivers. (Amankwah, 2013).

The general question raising concern with regards to today's mining activities includes the following: To what extent are these metallic pollutants dispersed, what levels of pollution these activities are generating, what is the impact on the water quality generally of the receiving water bodies and how these activities do affects the characteristics of the river beds (sediments). To address these issues, this study had the following objectives: To map out areas within the Konongo Municipality (Ashante Region) where illegal mining activities are prevalent and surface water bodies that are directly affected, To assess the impact of the mining activities on the water quality of the affected water bodies and To assess the level of pollution of the river sediments and the extent of dispersion of the metallic pollutant.

\section{Materials and Methods}

\section{Study Area}

The Asante Akim North Municipal Assembly is one of the 27 Districts in the Ashanti region. It has KonongoOdumase as its twin capital town. The municipality is located in the Eastern part of the Ashanti Region and lies between latitude 60 30' North and 70 30' North and longitude $0015^{\prime}$ 'West and 10 20' West. It covers a land area of $1,160 \mathrm{Km}^{2}$ with an estimated population of 142,434 in 2006 (Source: National population and housing census 2000). The Municipality shares boundaries with Sekyere east on the North, Kwahu South on the east, Asante Akim South on the south and Ejisu Juabeng Municipality on the west. The Municipality lies within semi-equatorial belt characterized by double rainfall maxima. The first rainy season starts from May to July and the second from
September to November. The dry harmattan season occurs between December and April and is associated with drought condition (Boadi et al., 2013). The annual rainfall of the Municipality averages between 150-170 mm. The daily temperature ranges from $22-30^{\circ} \mathrm{C}$ with minimum monthly temperature of $26^{\circ} \mathrm{C}$ and maximum temperature of $30^{\circ} \mathrm{C}$ recorded in March and April. The average humidity in the area is $75-80 \%$ (Boadi et al., 2013).

\section{Sampling and Physicochemical Analysis}

Water and sediment samples were taken from seven different locations within the rivers catchment. Two control points from the upstream where no mining activities is being carried out were sampled for each of the two streams and are shown on the map. A Geographical Positioning System (GPS) "Garmin 62SC" was used to take coordinates for each of the sampled points. Using WGS 84, both sediment and water samples for each of the sampling points were taken with all the coordinated points converted into shapefiles using the geographic coordinate system. Geographic bound was considered to limit us on the extent of the geographic area mapped but not the entire Konongo Township. Four different metals; Arsenic (As), Mercury ( $\mathrm{Hg}$ ), cadmium $(\mathrm{Cd})$ and Lead $(\mathrm{Pb})$ were considered for the analysis. Physiochemical parameters such as $\mathrm{p}^{\mathrm{H}}$, conductivity, Total Dissolved Solids (TDS) and turbidity were also measured. For heavy metal determination, complete digestion of sediment was done. The sediment samples were oven dried, grinded with mortar and pistle then sieved through 2 $\mathrm{mm}$ sieve. One gram of the sediment sample was weighed into a $250 \mathrm{~mL}$ conical flask. Ten milliliters of acid solution $\left(\mathrm{HNO}_{3}\right.$ and $\mathrm{HClO}_{4}$ in the ratio 9:4) was added to each of the sample. The mixture was heated gradually to $180^{\circ} \mathrm{C}$ until production of red nitrite fumes ceased. After which it was filtered using Whatman No. 1 filter paper in a $100 \mathrm{~mL}$ volumetric flask. The metals; $\mathrm{As}, \mathrm{Hg}, \mathrm{Cd}$ and $\mathrm{Pb}$ were analysed using Buck Scientific 210 VGP model (Flame Atomic Absorption Spectroscopy).

\section{Results}

From the survey of the study area and the coordinates taken using the GPS system, the following map (Fig. 1) was developed using the shape files.

\section{Statistics}

Means and standard deviations were reported where appropriate. Turkey's test was applied to identify significant differences in measured parameters among sampling points using IBM SPSS Statistics 20 software package. Pearson's correlation analysis was performed to evaluate potential relationships among the different variables. 


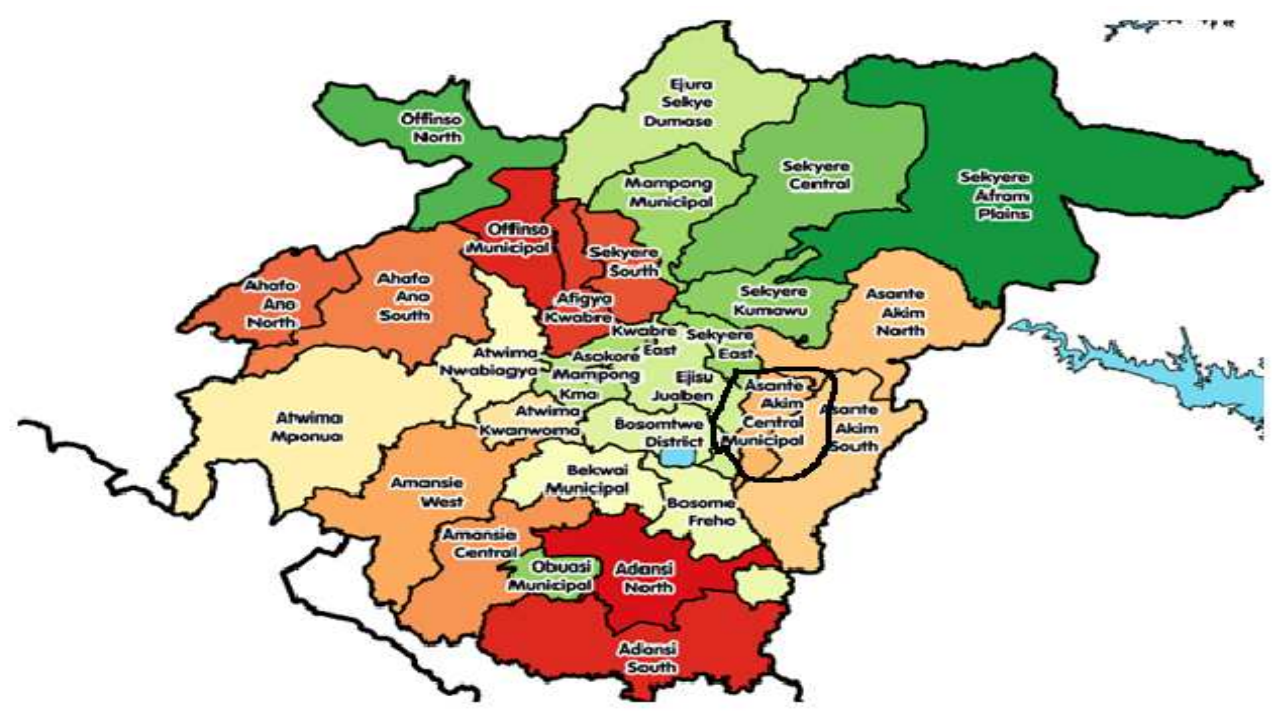

Fig. 1: Town map of Konongo

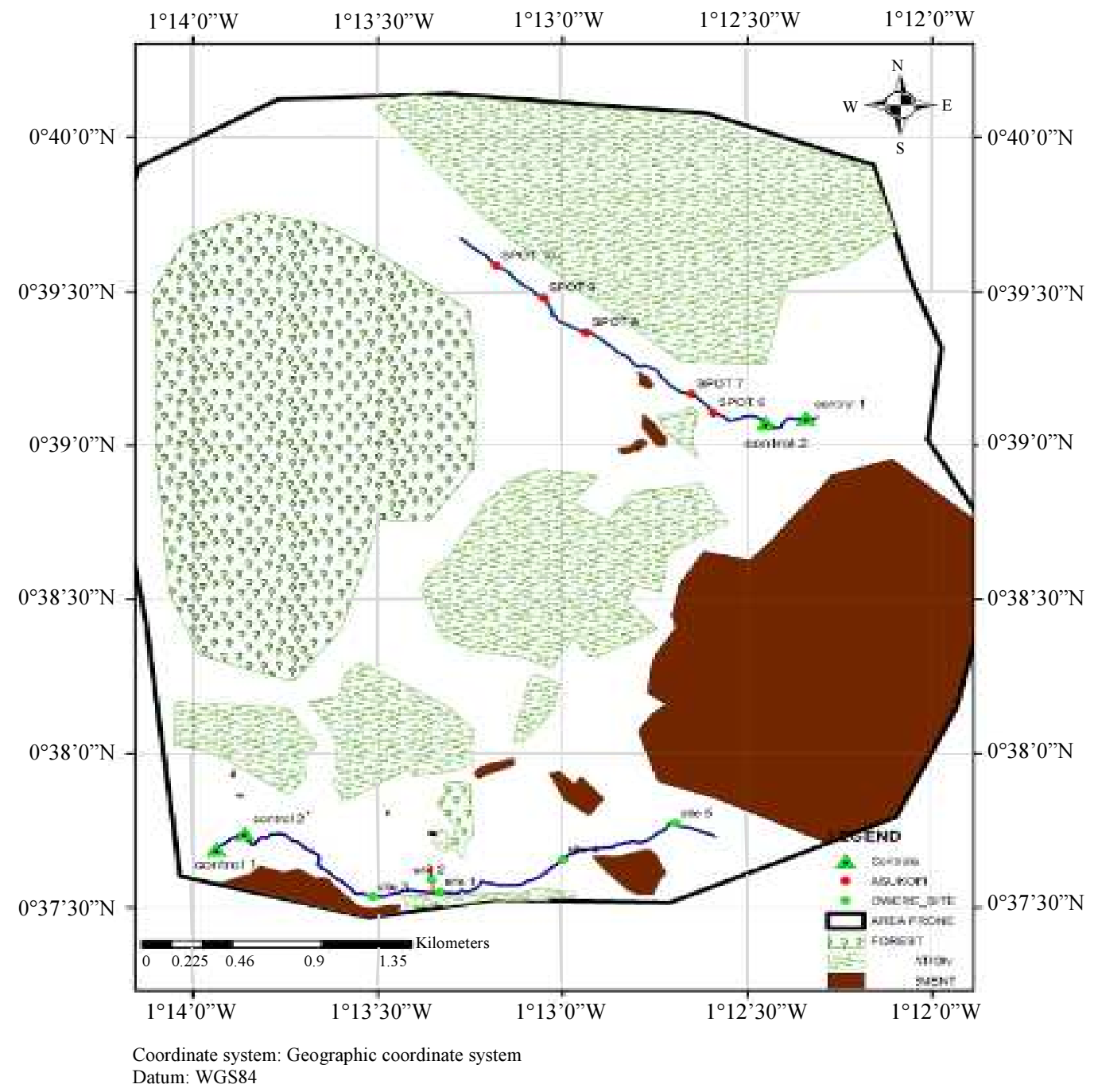

Fig. 2: Map indicating study area with sampled sites with controls 


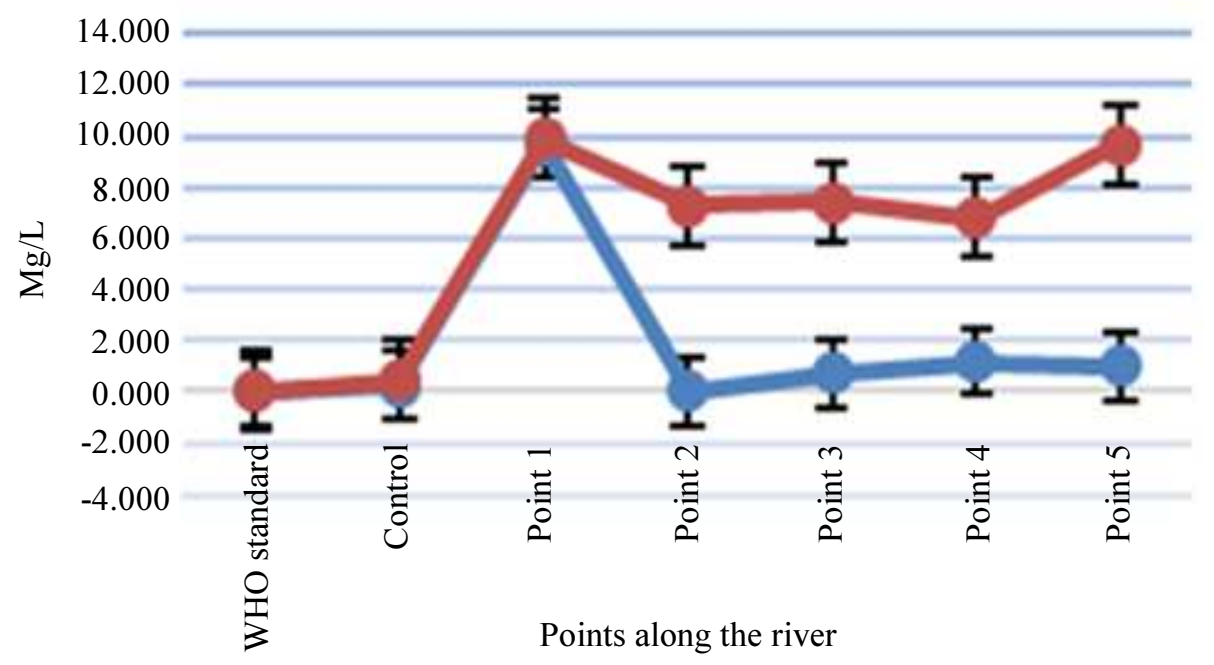

Owerri

Asuokofi

Fig. 3: Dispersion of Lead within both streams

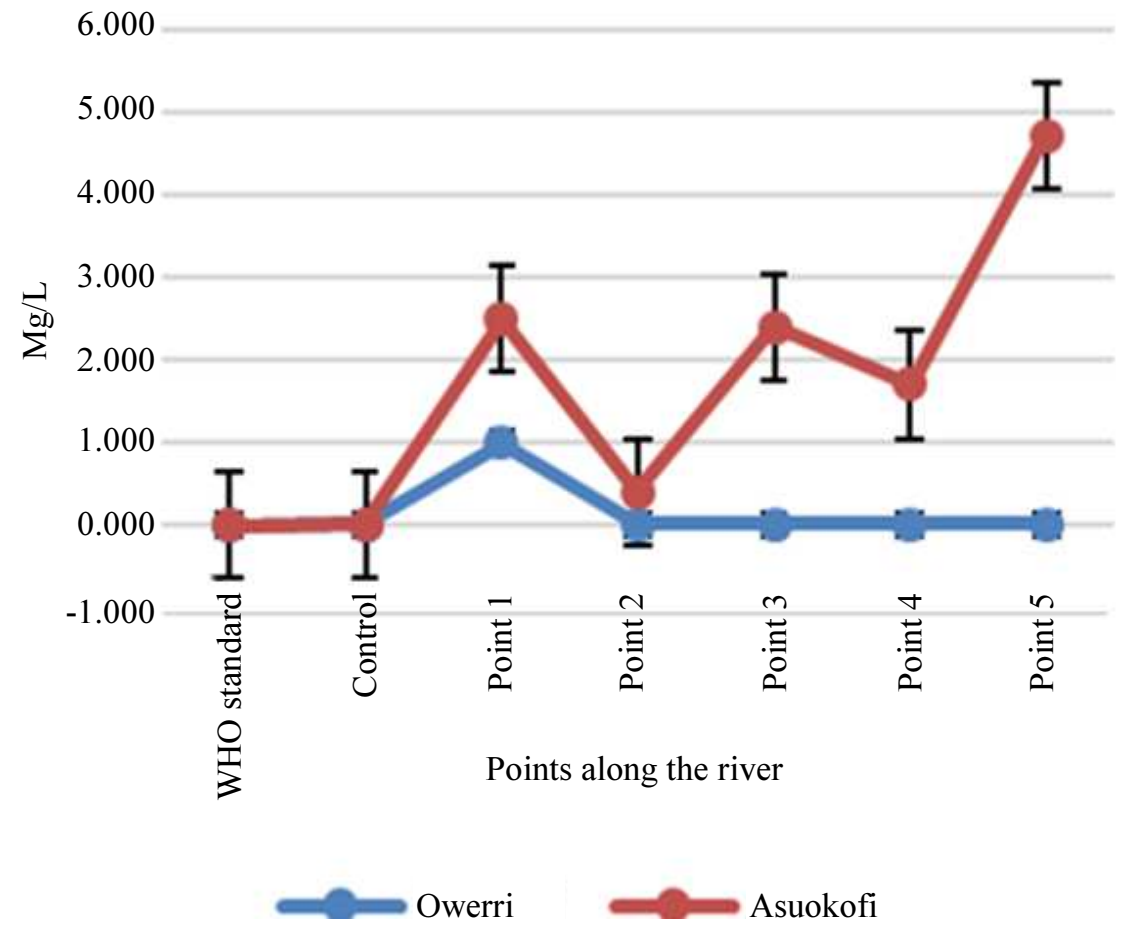

Fig. 4: Dispersion of Mercury within both streams

\section{Concentrations of Heavy Metals in Water}

Figure 3 to 6 indicate the concentration of the metal pollutants in the Owerri and Asuokofi streams. The mean concentrations of $\mathrm{Pb}, \mathrm{Hg}, \mathrm{As}$ and $\mathrm{Cd}$ in Owerri stream are respectively $2.5 \pm 3.7,0.2 \pm 0.4,0.2 \pm 0.2$ and $3.1 \pm 2$ $\mathrm{mg} \mathrm{L}^{-1}$. The mean concentrations of $\mathrm{Pb}, \mathrm{Hg}, \mathrm{As}$ and $\mathrm{Cd}$ in the Asuokofi stream are $8.2 \pm 1.3,2.3 \pm 1.8,25.3 \pm 22.2$ and $0.4 \pm 0.1 \mathrm{mg} \mathrm{L}^{-1}$ respectively. From Table 1 , the levels of $\mathrm{Pb}, \mathrm{Hg}, \mathrm{As}$ and $\mathrm{Cd}$ within the two streams are very significant, having their respective significant levels less than 0.05 confidence levels. 


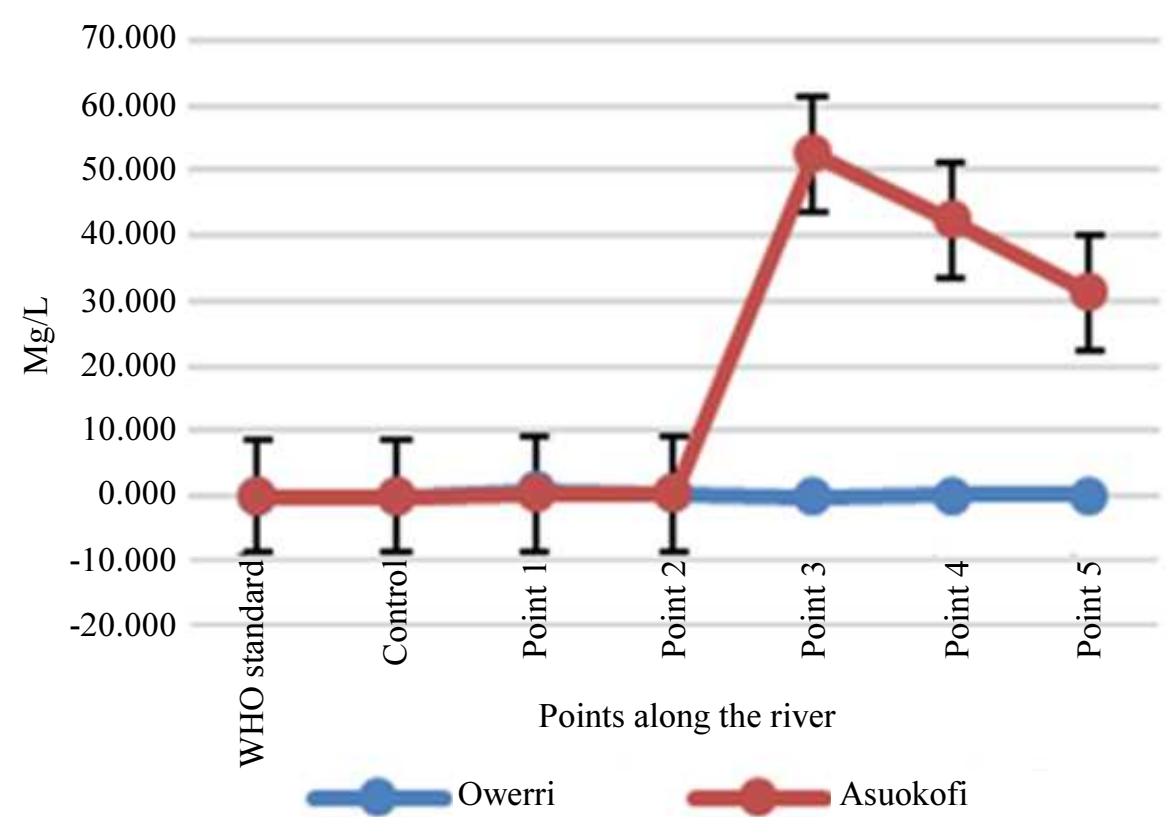

Fig. 5: Dispersion of Arsenic within both streams
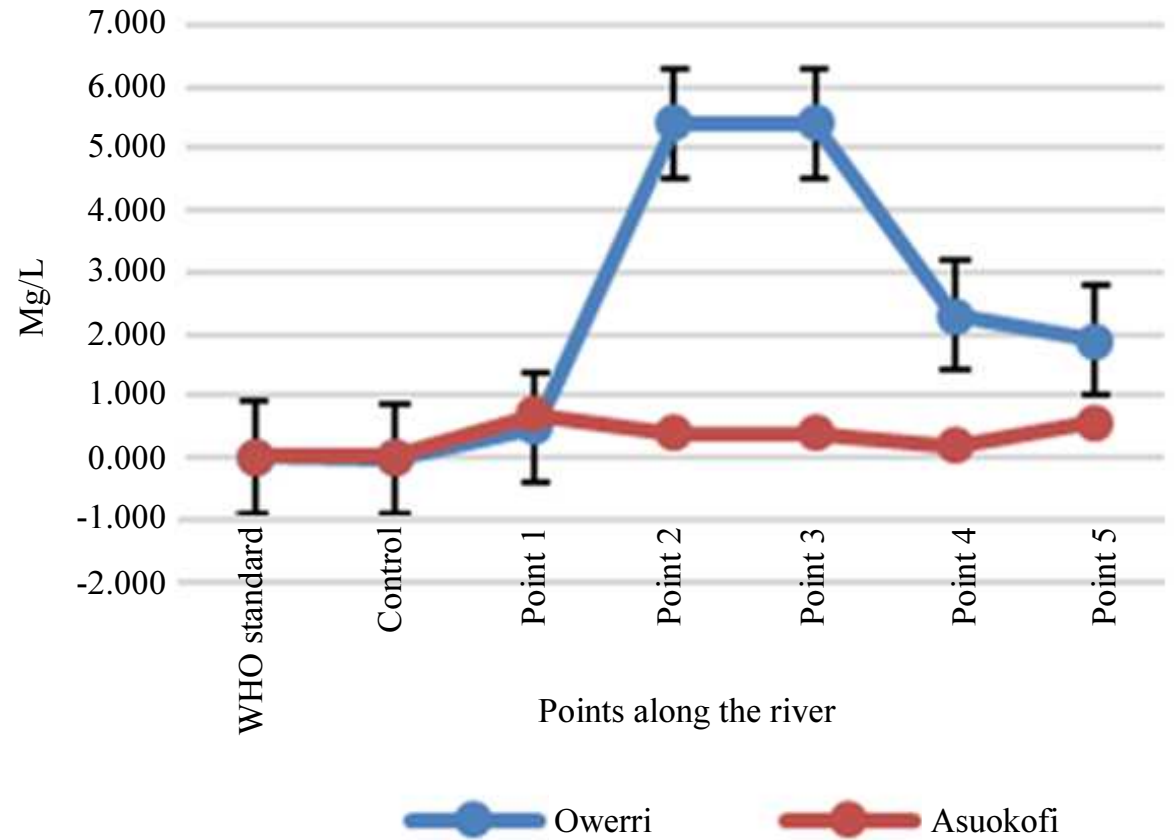

Asuokofi

Fig. 6: Dispersion of Cadmium within both streams

\section{Concentrations of Heavy Metals in the River Sediments}

Figures 7 to 10 indicate the concentration of the metal pollutants in the sediments of Owerri and Asuokofi streams. The mean concentrations of $\mathrm{Pb}, \mathrm{Hg}$, $A s$ and $C d$ in Owerri stream are $52.2 \pm 28,0.35 \pm 0.5$, $492.5 \pm 365.8$ and $1.7 \pm 2.08 \mathrm{mg} \mathrm{kg}^{-1}$ respectively. The mean concentrations of $\mathrm{Pb}, \mathrm{Hg}, \mathrm{As}$ and $\mathrm{Cd}$ in the
Asuokofi stream are $12 \pm 0.7,2.7 \pm 0.4,21.2 \pm 13.5$ and $1.6 \pm 0.4 \mathrm{mg} \mathrm{kg}^{-1}$ respectively. From Table 2, the difference in the concentration of $P b$ between the two streams is very significant $(P$-value of 0.00$)$. This is indicative of the fact that the levels of $P b$ are significantly higher in the Owerri stream than the Asuokofi stream. The differences in concentrations of $\mathrm{Hg}$ are significantly higher in the Asuokofi stream than that of the Owerri stream (P-value of 0.00$)$. 


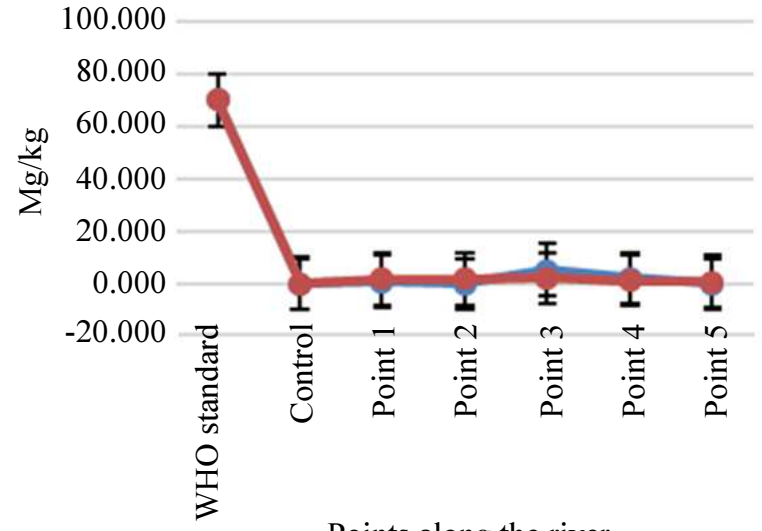

Points along the river

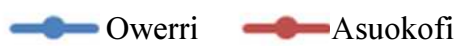

Fig. 7: Dispersion of Cadmium within sediments

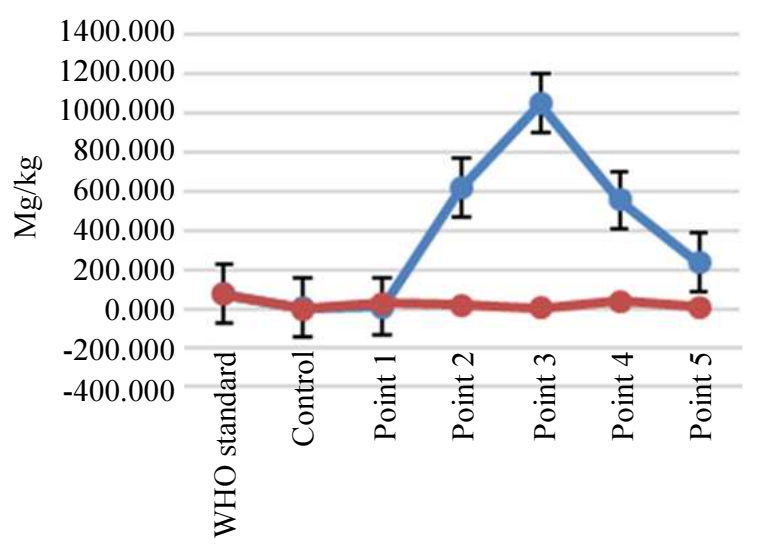

Points along the river

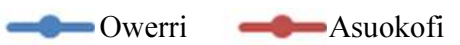

Fig. 8: Dispersion of Arsenic within sediments

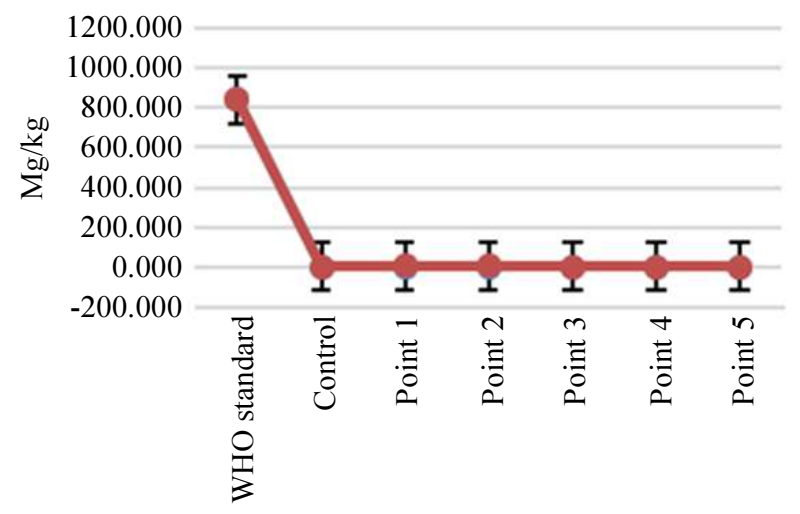

Points along the river

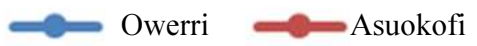

Fig. 9: Dispersion of Mercury within sediments 


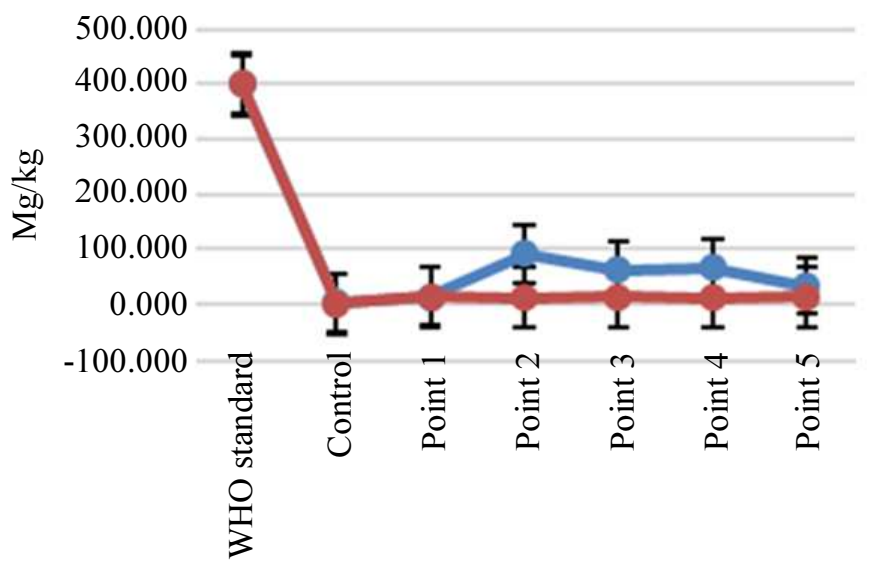

Points along the river

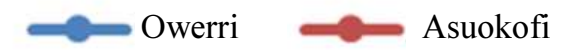

Fig. 10: Dispersion of Lead within sediments

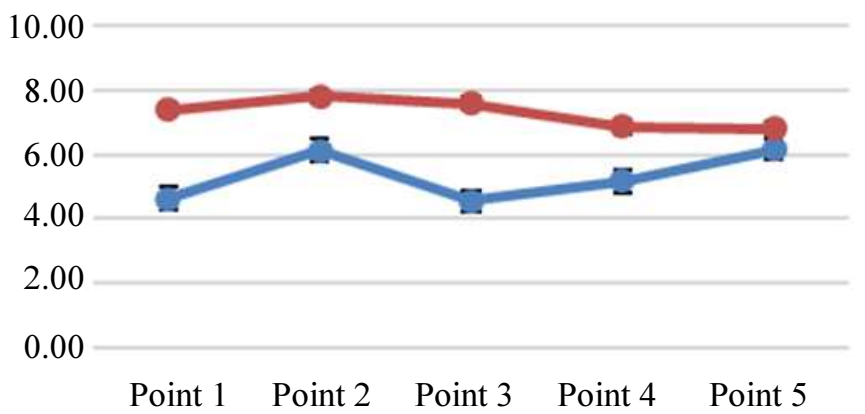

Points along the river

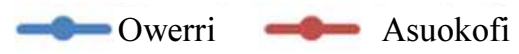

Fig. 11: Levels of $\mathrm{P}^{\mathrm{H}}$ along the streams

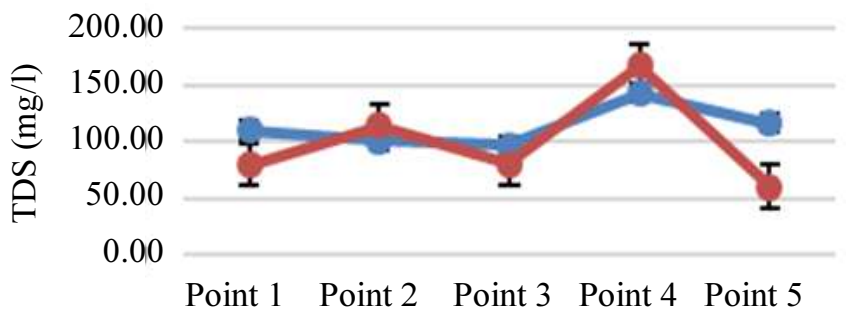

Points along the river

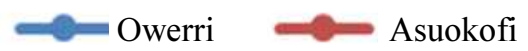

Fig. 12: Levels of TDS along the stream 


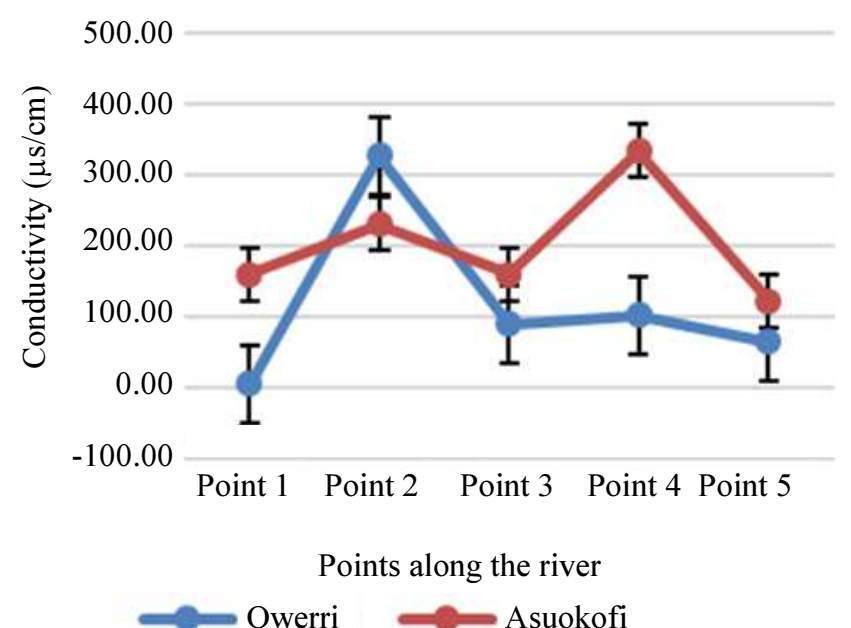

Fig. 13: Levels of Conductivity along the streams

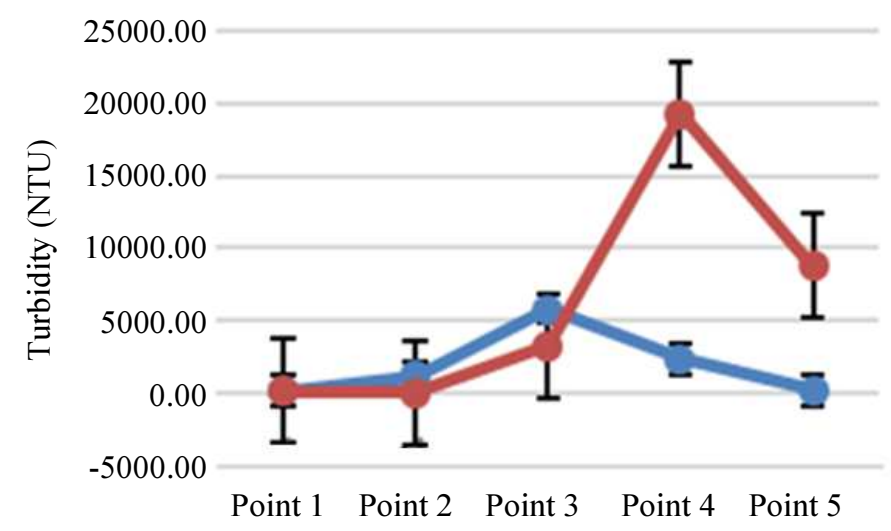

Points along the river

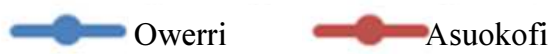

Fig. 14: Levels of Turbidity along the streams

Table 1: Levels of significance of pollutant within the streams t-test for equality of means

\begin{tabular}{|c|c|c|c|c|c|c|c|}
\hline \multirow[b]{2}{*}{$\begin{array}{l}\text { Independent } \\
\text { samples test }\end{array}$} & \multirow[b]{2}{*}{$\mathrm{t}$} & \multirow[b]{2}{*}{ df } & \multirow[b]{2}{*}{$\begin{array}{l}\text { Sig. } \\
\text { (2-tailed) }\end{array}$} & \multirow[b]{2}{*}{$\begin{array}{l}\text { Mean } \\
\text { difference }\end{array}$} & \multirow[b]{2}{*}{$\begin{array}{l}\text { Std. error } \\
\text { Difference }\end{array}$} & \multicolumn{2}{|c|}{$95 \%$ confidence interval of the difference } \\
\hline & & & & & & Lower & Upper \\
\hline \multirow[t]{2}{*}{ Lead $(\mathrm{Pb})$} & -5.534 & 28.000 & 0.000 & -5.7018000 & 1.0302711 & -7.8122146 & -3.5913854 \\
\hline & -5.534 & 17.705 & 0.000 & -5.7018000 & 1.0302711 & -7.8689107 & -3.5346893 \\
\hline \multirow{2}{*}{ Mercury (Hg) } & -4.307 & 28.000 & 0.000 & -2.1383133 & 0.4964505 & -3.1552460 & -1.1213807 \\
\hline & -4.307 & 15.338 & 0.001 & -2.1383133 & 0.4964505 & -3.1944464 & -1.0821803 \\
\hline \multirow[t]{2}{*}{ Arsenic (As) } & -4.360 & 28.000 & 0.000 & -25.0910000 & 5.7551009 & -36.8797898 & -13.3022102 \\
\hline & -4.360 & 14.004 & 0.001 & -25.0910000 & 5.7551009 & -37.4340935 & -12.7479065 \\
\hline \multirow[t]{2}{*}{ Cadmium $(\mathrm{Cd})$} & 5.000 & 28.000 & 0.000 & 2.6446667 & 0.5289233 & 1.5612164 & 3.7281170 \\
\hline & 5.000 & 14.215 & 0.000 & 2.6446667 & 0.5289233 & 1.5118440 & 3.7774893 \\
\hline
\end{tabular}


Table 2: Independent samples test in sediments

t-test for equality of means

\begin{tabular}{|c|c|c|c|c|c|c|c|}
\hline \multirow[b]{2}{*}{$\begin{array}{l}\text { Dependent } \\
\text { variables }\end{array}$} & \multirow[b]{2}{*}{$\mathrm{t}$} & \multirow[b]{2}{*}{$\mathrm{df}$} & \multirow[b]{2}{*}{$\begin{array}{l}\text { Sig. } \\
\text { (2-tailed) }\end{array}$} & \multirow[b]{2}{*}{$\begin{array}{l}\text { Mean } \\
\text { difference }\end{array}$} & \multirow[b]{2}{*}{$\begin{array}{l}\text { Std. error } \\
\text { difference }\end{array}$} & \multicolumn{2}{|c|}{$95 \%$ confidence interval of the difference } \\
\hline & & & & & & Lower & Upper \\
\hline \multirow{2}{*}{ Lead $(\mathrm{Pb})$} & 5.545 & 28.000 & 0.000 & 40.2066667 & 7.2509744 & 25.3537190 & 55.0596143 \\
\hline & 5.545 & 14.018 & 0.000 & 40.2066667 & 7.2509744 & 24.6567502 & 55.7565831 \\
\hline \multirow[t]{2}{*}{ Mercury (Hg) } & -12.580 & 28.000 & 0.000 & -2.4241033 & 0.1926997 & -2.8188307 & -2.0293759 \\
\hline & -12.580 & 25.923 & 0.000 & -2.4241033 & 0.1926997 & -2.8202603 & -2.0279463 \\
\hline \multirow[t]{2}{*}{ Arsenic (As) } & 4.986 & 28.000 & 0.000 & 471.2400000 & 94.5135942 & 277.6376787 & 664.8423213 \\
\hline & 4.986 & 14.038 & 0.000 & 471.2400000 & 94.5135942 & 268.5801590 & 673.8998410 \\
\hline \multirow{2}{*}{ Cadmium $(\mathrm{Cd})$} & 0.131 & 28.000 & 0.897 & .0726667 & 0.5535669 & -1.0612637 & 1.2065971 \\
\hline & 0.131 & 15.548 & 0.897 & .0726667 & 0.5535669 & -1.1036240 & 1.2489574 \\
\hline
\end{tabular}

The differences in concentrations of $A s$ are significantly higher in the Owerri river than that of Asuokofi (P-value of 0.00). But the differences in concentrations of $C d$ between Owerria and Asukofi is not significant $(P$-value is $0.897>0.005)$.

\section{Physicochemical Analysis}

Four physicochemical parameter analysed within the catchment are $\mathrm{p}^{\mathrm{H}}$, Total Dissolve solids, conductivity and turbidity with their respective mean values shown the Fig. 11-14.

\section{Discussion}

The results of dispersion of the metallic pollutants within the Owerri and Asuokofi streams are clearly shown above. The levels of almost all the heavy metallic pollutants under consideration in both streams especially Asuokofi are well dispersed well above the WHO guidelines and the control point levels along the flow lines. There is a gradual increase in the levels of pollutants from the upstream to the downstream. Though the samplings were done during the raining season yet the levels in both the water and sediments are high, it can be envisaged that there might be much higher levels of the heavy metals in the water and sediments during the dry season. There is the tendency of the concentrations of pollutants in the sediments to further dissolve in the water whenever there is a disturbance at the bed of the streams which may further increasing the levels of the metal way above the World Health Organisation (WHO) standards thereby endangering the lives of the communities. From the map shown in Fig. 2, most of the vegetation/farmlands and settlements are very close to these streams where the illegal mining is being carried out of which the communities rely heavily for irrigation and other domestic use. The high levels of the heavy metals in the sediments give rise for concern on the impact of food security in the area. There is the tendency for the crops grown within the mining enclave to pick up some of the heavy metals and subsequently to be consumed by both man and animals.
The Physicochemical parameters analysed from the two streams are; $\mathrm{P}^{\mathrm{H}}$, Conductivity, TDS and Turbidity. The $\mathrm{p}^{\mathrm{H}}$ values obtained ranged from 5.3 to 7.2 . With the exception of Turbidity, all the samples fell within the WHO range for potable water. The mild acidic increase in the water samples increased the capacity of the water to attack geological materials and leach toxic trace metals into the water.

In the case of turbidity, the values ranged between 1946.6 to $2177.5 \mathrm{NTU}$ far above, the limit 5NTU. The Electrical Conductivity (EC) for all samples fell within the permissible limit of $500 \mu \mathrm{S} \mathrm{cm}^{-1}$ set by WHO. EC is an indicator of water quality and soil salinity, hence the relatively high values observed in some water samples showed high salinity; thus the waters might not be very suitable for domestic and agricultural use. TDS values are generally below $250 \mathrm{mg} \mathrm{L}^{-1}$ which was within the WHO permissible limit for potable water this showed that the two stream water in the area was quite fresh in most locations. The presence of the TDS in the water samples as observed in Fig. 12 above indicated the presence of solid materials or solutes in the water.

\section{Conclusion and Recommendation}

The results of this study supply valuable information about some heavy metal contents of sediments and water from different sites along Owerri and Asuokofi streams and we can conclude and recommended that:

- The activities of illegal mining in Konongo area has really polluted the water bodies especially their main source of water; Owerri and Asuokofi streams

- The distribution pattern of the heavy metals under investigation in stream sediments and water reflected a high significant difference $(\mathrm{p}<0.01)$ for the all measured metals

- The levels of the metals are higher in the sediments than the water

- All the streams in the study area showed high levels of turbidity and conductivity 
- It is recommended that the activities of the illegal mining must be curtailed immediately

- The metals in the sediments and water of the streams should be remediated preferably engaging the phenomenon of phytoremediation

\section{Acknowledgement}

This study was funded by the Regional Water and Environmental Sanitation Centre, Kumasi (RWESCK) at the Kwame Nkrumah University of Science and Technology, Kumasi with funding from Ghana Government and the World Bank under the Africa Centre's of Excellence project'. The views expressed in this paper do not reflect those of the World Bank, Ghana Government and KNUST.

\section{Authors Contributions}

Wiafe, Samuel: Participated in all the experiments, coordinated the data analysis and contributed to the writing of the manuscript.

Richard Buamah: Designed the research plan and organized the study.

Helen Essandoh: Participated in the experiments and data analysis.

Lawrence Darkwah: Participated in the experiments and writing of the manuscript.

\section{Ethics}

This article is original and contains unpublished material. The corresponding author confirms that all of the other authors have read and approved the manuscript and there are no ethical issues involved.

\section{References}

Amankwah, E., 2013. Impact of illegal mining on water resources for domestic and irrigation purposes. ARPN J. Earth Sci., 2: 117-121.

Boadi, B., D.D. Wemegah and K. Preko, 2013. Geological and structural interpretation of the Konongo area of the Ashanti gold belt of Ghana from aero-magnetic and radiometric data. Int. Res. J. Geol. Min., 3: 124-135.

Hilson, G. and S. Pardie, 2006. Mercury: An agent of poverty in Ghana's small-scale gold-mining sector? Resources Policy, 31: 106-116. DOI: 10.1016/j.resourpol.2006.09.001

Oduro, O.W., R. Bayitse, D. Carboo, B. Kortatsi and I. Hodgson, 2012. Assessment of dissolved mercury in surface water along the lower basin of the river pra in Ghana. Int. J. Applied Sci. Technol., 2: 228-235.

Swain, E.B., P.M. Jakus, G. Rice, F. Lupi and P.A. Maxson et al., 2007. Socioeconomic consequences of mercury use and pollution. AMBIO, 36: 45-61. DOI: $10.1579 / 0044-$ 